\title{
Arctic sea-ice melt in 2008 and the role of solar heating
}

\author{
Donald K. PEROVICH, ${ }^{1}$ Jacqueline A. RICHTER-MENGE, ${ }^{1}$ Kathleen F. JONES, ${ }^{1}$ \\ Bonnie LIGHT, ${ }^{2}$ Bruce C. ELDER, ${ }^{1}$ Christopher POLASHENSKI, ${ }^{3}$ Daniel LAROCHE, ${ }^{1}$ \\ Thorsten MARKUS, ${ }^{4}$ Ronald LINDSAY ${ }^{2}$
}

\author{
${ }^{1}$ US Army Engineer Research and Development Center, Cold Regions Research and Engineering Laboratory, 72 Lyme Road, \\ Hanover, NH 03755-1290, USA \\ E-mail: donald.k.perovich@usace.army.mil \\ ${ }^{2}$ Polar Science Center, Applied Physics Laboratory, University of Washington, 1013 NE 40th Street, Seattle, \\ WA 98105-6698, USA \\ ${ }^{3}$ Thayer School of Engineering, Dartmouth College, Hanover, NH 03755-0800, USA \\ ${ }^{4}$ NASA Goddard Space Flight Center, Code 614.1, Greenbelt, MD 20771, USA
}

\begin{abstract}
There has been a marked decline in the summer extent of Arctic sea ice over the past few decades. Data from autonomous ice mass-balance buoys can enhance our understanding of this decline. These buoys monitor changes in snow deposition and ablation, ice growth, and ice surface and bottom melt. Results from the summer of 2008 showed considerable large-scale spatial variability in the amount of surface and bottom melt. Small amounts of melting were observed north of Greenland, while melting in the southern Beaufort Sea was quite large. Comparison of net solar heat input to the ice and heat required for surface ablation showed only modest correlation. However, there was a strong correlation between solar heat input to the ocean and bottom melting. As the ice concentration in the Beaufort Sea region decreased, there was an increase in solar heat to the ocean and an increase in bottom melting.
\end{abstract}

\section{INTRODUCTION}

Arctic sea ice has undergone a dramatic decline in recent years, with a well-documented retreat of the summer ice cover (Serreze and others, 2007; Comiso and others, 2008), a general thinning (Giles and others, 2008; Haas and others, 2008; Rothrock and others, 2008; Kwok and others, 2009) and a transition to a younger, more vulnerable ice pack (Maslanik and others, 2007; Nghiem and others, 2007). A record September minimum ice extent was observed in 2007 (Stroeve and others, 2008) and was followed by the second smallest observed ice extent in 2008 (US National Snow and Ice Data Center, http://nside.org/arcticseaicenews/). Climate models project that these changes may continue, with a possible transition to ice-free summers later this century (Wang and Overland, 2009).

These observed changes are intricately linked to sea-ice dynamics and thermodynamics and are driven by atmosphere and ocean forcing. Several factors have been established as contributors to the decline in the ice cover: a general warming (Richter-Menge, 2009), changes in atmospheric circulation patterns (Rigor and Wallace, 2004), changes in cloudiness (Francis and Hunter, 2006; Kay and others, 2008), advected ocean heat from lower latitudes (Polyakov and others, 2003; Shimada and others, 2006; Woodgate and others, 2006), increased ice export from the Fram Strait (Nghiem and others, 2007) and increased solar heating of the upper ocean (Perovich and others, 2007, 2008; Steele and others, 2008).

Sea-ice mass balance can provide insights into the thermodynamic influences on the declining ice cover. The mass balance is the difference between the amount of ice growth during the winter and the amount of surface and bottom melt during the summer. The mass balance is an integrator of both the surface heat budget and the ocean heat flux and thus provides a way to attribute observed changes in ice extent and ice thickness. In this paper, we examine observations of surface and bottom melting made from seven autonomous ice mass-balance buoys during the summer of 2008. Observed melting is compared to calculated estimates of solar radiation incident on the ice and transmitted directly into the ocean.

\section{APPROACH}

The ice mass balance was measured using autonomous ice mass-balance buoys (IMBs) (Richter-Menge and others, 2006; Perovich and others, 2008). These buoys monitor changes in snow deposition and ablation, ice growth, and ice surface and bottom melt. Two acoustic rangefinders monitor the position of the ice bottom and the snow/ice surface. A string of thermistors measures vertical profiles of ice temperature. Ancillary data from the IMBs include barometric pressure, air temperature (initially $2 \mathrm{~m}$ above the surface), water temperature (initially $\sim 0.5 \mathrm{~m}$ below the ice bottom), and position. Data are recorded using a Campbell Scientific data logger and are transmitted using the ARGOS (Advanced Research and Global Observation Satellite) system.

These buoys have routinely been deployed on undeformed multi-year sea ice in the Arctic since 2000, typically in conjunction with other sensor packages studying the atmosphere and ocean. As part of the 2007-09 International Polar Year (IPY), we were able to expand the number of buoys deployed. The IPY deployments were done in collaboration with the North Pole Environmental Observatory (Morison and others, 2002), the Beaufort Gyre Environmental Observatory and the DAMOCLES program (Developing Arctic Modeling and Observing Capabilities for Long-term Environmental Studies) (Gascard and others, 2008). 


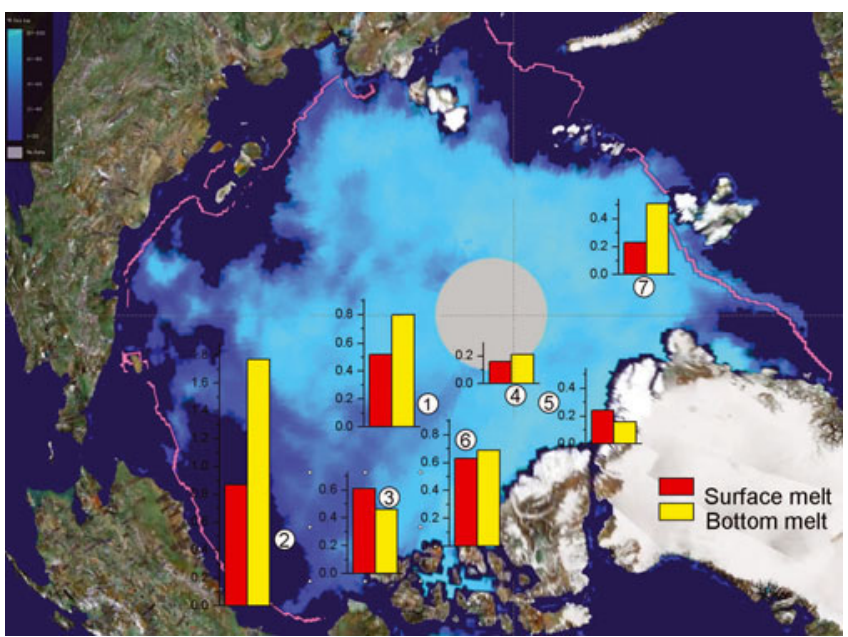

Fig. 1. The total amount of surface (red) and bottom (yellow) melt during the summer of 2008 measured at seven IMBs. The white dots denote an approximate position of the buoy during summer. The ice at buoy 2 completely melted. Also displayed is a map of the ice concentration in September 2008 from the US National Snow and Ice Data Center. The pink line represents the average September ice extent for 1979-2000.

\section{RESULTS AND DISCUSSION}

Seven IMBs operated during the summer of 2008. One was installed in 2006, another in 2007 and five in 2008. These buoys were located primarily in the western Arctic. Figure 1 shows the approximate summer position (white dot), the total amount of surface ablation (red bar) and the total bottom melt (yellow bar) for the summer of 2008. All of the buoys were installed in undeformed multi-year ice, with end-of-winter ice thicknesses ranging from 1.83 to $3.17 \mathrm{~m}$ (Table 1). There was considerable regional variability in the amount of surface, bottom and total melting. The smallest amount of melting was at a location north of Greenland, where $0.3 \mathrm{~m}$ of surface ablation and $0.1 \mathrm{~m}$ of bottom melt resulted in a total thinning of only $0.4 \mathrm{~m}$. The maximum melting was in the Beaufort Sea, where $3.2 \mathrm{~m}$ of thick ice completely melted by 23 August 2008, with $0.87 \mathrm{~m}$ of surface ablation and $1.77 \mathrm{~m}$ of bottom melt measured before the buoy failed. On average, there was $0.47 \mathrm{~m}$ of surface melting and $0.66 \mathrm{~m}$ of bottom melting.

The background map in Figure 1 displays ice concentration in September 2008. A casual examination shows a tendency towards greater bottom ablation in regions of lower ice concentration. The largest observed bottom melting was at the ice-edge site in the Beaufort Sea, while the smallest was north of Greenland where the ice concentration was large throughout the summer. There were also large amounts of bottom melting in the Beaufort Sea in the summer of 2007, due in part to enhanced solar heating of the upper ocean (Perovich and others, 2008).

We can examine ocean solar heating in 2008 in more detail by calculating estimates of local solar heating at each of the seven buoy locations. The flux of solar heat input directly to the upper ocean $\left(F_{\mathrm{rw}}\right)$ through leads can be estimated using the relationship

$$
F_{\mathrm{rw}}=F_{\mathrm{r}}\left(1-\alpha_{\mathrm{w}}\right)\left(1-I_{\mathrm{c}}\right),
$$

where $F_{\mathrm{r}}$ is the incident solar irradiance, $\alpha_{\mathrm{w}}$ is the albedo of the ocean and $I_{\mathrm{C}}$ is the ice concentration. $F_{\mathrm{r}}$ and $I_{\mathrm{C}}$ are determined for a cell containing an IMB using a
$25 \mathrm{~km} \times 25 \mathrm{~km}$ Equal-Area Scalable Earth Grid (EASE-Grid). The albedo of water was set to 0.07 (Pegau and Paulson, 2001). Values of $F_{\mathrm{r}}$ were obtained from adjusted US National Centers for Environmental Prediction (NCEP) values. The area of open water was determined from passive microwave observations by using the NASA Team 2 algorithm (Markus and Cavalieri, 2000).

Mean daily downwelling shortwave fluxes from the NCEP Reanalysis are known to have large biases due to incorrect cloud fractions, in contrast to those of the European Centre for Medium-Range Weather Forecasts reanalysis (ERA-40; Serreze and others, 1998; Walsh and others, 2009) which has a more realistic seasonal cycle for the clouds but ends in 2002. However, the fluxes in the two reanalyses are well correlated if seasonal and geographic variations are accounted for (Liu and others, 2005). Seasonal and regional regression equations were determined between the two datasets so that the more recent NCEP Reanalysis data could be adjusted to match the more precise ERA-40 values. The NCEP predictor variables are the downwelling solar flux and the sea-level pressure. Five years of data were used (evenly spaced from 1979 to 1999), and separate regression equations were determined every 5 days of the seasonal cycle for every second gridpoint of the NCEP data. The mean rootmean-square error of the regression fits is $29 \mathrm{~W} \mathrm{~m}^{-2}$ for the daily means.

Additional solar energy is also transmitted to the upper ocean through the ice, but that amount is neglected in this analysis. The amount of solar heat transmitted through the ice depends primarily on ice thickness and pond fraction, parameters that are not known for our study. Perovich (2005), using field observations from the Surface Heat Budget of the Arctic Ocean (SHEBA) program and a radiative transfer model, determined that leads were the major source of solar energy deposited in the ocean $(61 \%)$, but that bare ice $(23 \%)$ and ponded ice $(16 \%)$ also contributed significantly.

Equation (1) was evaluated every day from 1 January 2008 to 16 October (end of melt) for each of the seven 2008 IMB sites and integrated over time to obtain the heat input to the upper ocean $\left(Q_{\mathrm{w}}\right)$. The heat absorbed in the ocean was averaged over the entire ice-ocean area of the gridcell area.

The solar heat input to the ice $\left(F_{\mathrm{ri}}\right)$ is

$$
F_{\mathrm{ri}}=F_{\mathrm{r}}\left(1-\alpha_{\mathrm{i}}\right),
$$

where $\alpha_{\mathrm{i}}$ is the albedo of the ice. This heat would be available for melting at the ice surface and interior. As stated above, the small fraction that would be transmitted through the ice into the ocean is neglected. The key to evaluating Equation (2) is determining the time-dependent evolution of albedo. We assumed that the ice albedo evolved from cold snow (0.85) to wet snow (0.81) to melting snow (decrease from 0.81 to 0.65 ) to bare ice (0.65), and then back to snowcovered ice after fall freeze-up (Perovich and others, 2002). The timing of the albedo transitions was determined from satellite estimates of the onset of melt and freeze-up (Markus and others, 2009). The method distinguishes between early melt (the first day of the year when melt is detected) and the first day of continuous melt (when melt conditions prevail for the rest of the summer). A similar distinction is made for freeze-up. Fall freeze-up is taken as the day that freeze-up is first detected. Using this approach for albedo, Equation (2) was evaluated daily and then integrated over the duration of the surface melt period for each of the buoys to obtain the heat input to the ice $\left(Q_{\mathrm{i}}\right)$. 
Table 1. Summary of results from IMBs in the summer of 2008. Tabulated are snow depths $\left(H_{\mathrm{s}}\right)$, ice thicknesses before $\left(H_{\mathrm{i}}\right)$ and after $\left(H_{\mathrm{f}}\right)$ melt, the amount of surface and bottom melt, solar heat input to the ice $\left(Q_{\mathrm{i}}\right)$ and ocean $\left(Q_{\mathrm{w}}\right)$, and the heat used for surface melting $\left(Q_{\mathrm{ms}}\right)$ and bottom melting $Q_{\mathrm{mb}}$. Surface melting includes both snow and ice. Snow depths are just prior to the onset of melt. Buoy 2 failed before the ice cover at that site completely melted in August 2008

\begin{tabular}{|c|c|c|c|c|c|c|c|c|c|}
\hline \multirow{4}{*}{ Buoy } & \multirow{4}{*}{$\begin{array}{l}H_{\mathrm{s}} \\
\mathrm{m}\end{array}$} & \multirow{4}{*}{$\begin{array}{l}H_{\mathrm{i}} \\
\mathrm{m}\end{array}$} & \multirow{4}{*}{$\begin{array}{l}H_{\mathrm{f}} \\
\mathrm{m}\end{array}$} & \multirow{4}{*}{$\begin{array}{c}\text { Surface melt } \\
\text { m }\end{array}$} & \multirow{4}{*}{$\begin{array}{l}\text { Bottom melt } \\
\mathrm{m}\end{array}$} & \multicolumn{2}{|c|}{ Surface } & \multicolumn{2}{|c|}{ Bottom } \\
\hline & & & & & & Used & Available & Used & Available \\
\hline & & & & & & $Q_{\mathrm{ms}}$ & $Q_{\mathrm{i}}$ & $Q_{\mathrm{mb}}$ & $Q_{w}$ \\
\hline & & & & & & $M J \mathrm{~m}^{-2}$ & $\mathrm{MJ} \mathrm{m^{-2 }}$ & $\mathrm{MJ} \mathrm{m^{-2 }}$ & $\mathrm{MJ} \mathrm{m^{-2 }}$ \\
\hline 1 & 0.20 & 1.83 & 0.51 & 0.52 & 0.80 & 178 & 305 & 240 & 390 \\
\hline 2 & 0.07 & 3.17 & 0.53 & 0.87 & 1.77 & 269 & 635 & 532 & 640 \\
\hline 3 & 0.10 & 2.90 & 1.83 & 0.61 & 0.46 & 194 & 524 & 138 & 244 \\
\hline 4 & 0.16 & 2.13 & 1.76 & 0.16 & 0.21 & 66 & 417 & 63 & 151 \\
\hline 5 & 0.42 & 2.79 & 2.39 & 0.24 & 0.16 & 118 & 382 & 48 & 131 \\
\hline 6 & 0.08 & 2.92 & 1.60 & 0.63 & 0.69 & 198 & 428 & 207 & 240 \\
\hline 7 & 0.15 & 1.99 & 1.25 & 0.23 & 0.51 & 86 & 300 & 153 & 193 \\
\hline
\end{tabular}

The role of solar heating is illustrated in Figure 2 by comparing results from the IMBs with the least amount of melting (buoy 5) and the most (buoy 2). The Beaufort site had $0.87 \mathrm{~m}$ of surface ablation and $1.77 \mathrm{~m}$ of bottom melt, compared with only $0.24 \mathrm{~m}$ of surface ablation and $0.16 \mathrm{~m}$ of bottom melt at the site north of Greenland. Figure 2 compares time-series results of incident shortwave irradiance, ice concentration, heat input to the ocean, ice albedo, and heat input to the ice for these two IMBs. The incident solar irradiance for the two cases (Fig. 2a) is quite similar, with the curves crossing multiple times. The difference, integrated over the summer, is only a few percent, not nearly enough to explain the large differences in observed melt. There was an enormous difference in ice concentration between the two sites, with the Beaufort Sea site always having a smaller ice concentration and reaching open water in late August. This resulted in the solar heat input to the ocean always being larger at the Beaufort site (Fig. 2c). The total solar heat input to the ocean at the Beaufort site was three times as large as at the site north of Greenland (390 versus $131 \mathrm{MJ} \mathrm{m}^{-2}$ ). Estimated albedos for the two sites are presented in Figure $2 \mathrm{~d}$. The main difference is that melting at the Beaufort site started 21 days earlier. This led to a lower albedo for June and greater solar heat input to the ice (Fig. 2e). The ice albedo in June is critical to the surface heat budget, since June is typically the month of peak solar input at the surface.

We can further explore the relationship between solar heat input and melt by comparing the solar heat input to the amount of heat used in melting per square meter on the surface $\left(Q_{\mathrm{ms}}\right)$ and bottom $\left(Q_{\mathrm{mb}}\right)$ of the ice. Snowmelt is included in the surface melting calculation:

$$
\begin{gathered}
Q_{\mathrm{ms}}=\rho_{\mathrm{s}} L_{\mathrm{f}} \Delta H_{\mathrm{s}}+\rho_{\mathrm{i}} L_{\mathrm{f}} \Delta H_{\mathrm{i}} \\
Q_{\mathrm{mb}}=\rho_{\mathrm{i}} L_{\mathrm{f}} \Delta H_{\mathrm{b}}
\end{gathered}
$$

where $\rho_{\mathrm{s}}$ is the density of Arctic snow $\left(330 \mathrm{~kg} \mathrm{~m}^{-3}\right), \rho_{\mathrm{i}}$ is the density of ice $\left(900 \mathrm{~kg} \mathrm{~m}^{-3}\right), L_{\mathrm{f}}$ is the latent heat of fusion of ice $\left(334 \mathrm{~kJ} \mathrm{~kg}^{-1}\right), \Delta H_{\mathrm{s}}$ is the amount of snowmelt, $\Delta H_{\mathrm{i}}$ is the amount of surface ice melt and $\Delta H_{\mathrm{b}}$ is the amount of bottom ice melt.

Using the observed surface and bottom melting, Equations (3) and (4) were evaluated for each of the buoys. The heat used in surface melting ranged from 66 to $269 \mathrm{MJ} \mathrm{m}^{-2}$, while the bottom melting heat varied from 48 to $532 \mathrm{MJ} \mathrm{m}^{-2}$ (Table 1). The relationship between the heat used in melting and solar heat input is shown in Figure 3. Examining surface melting, there is a general weak trend relating increased

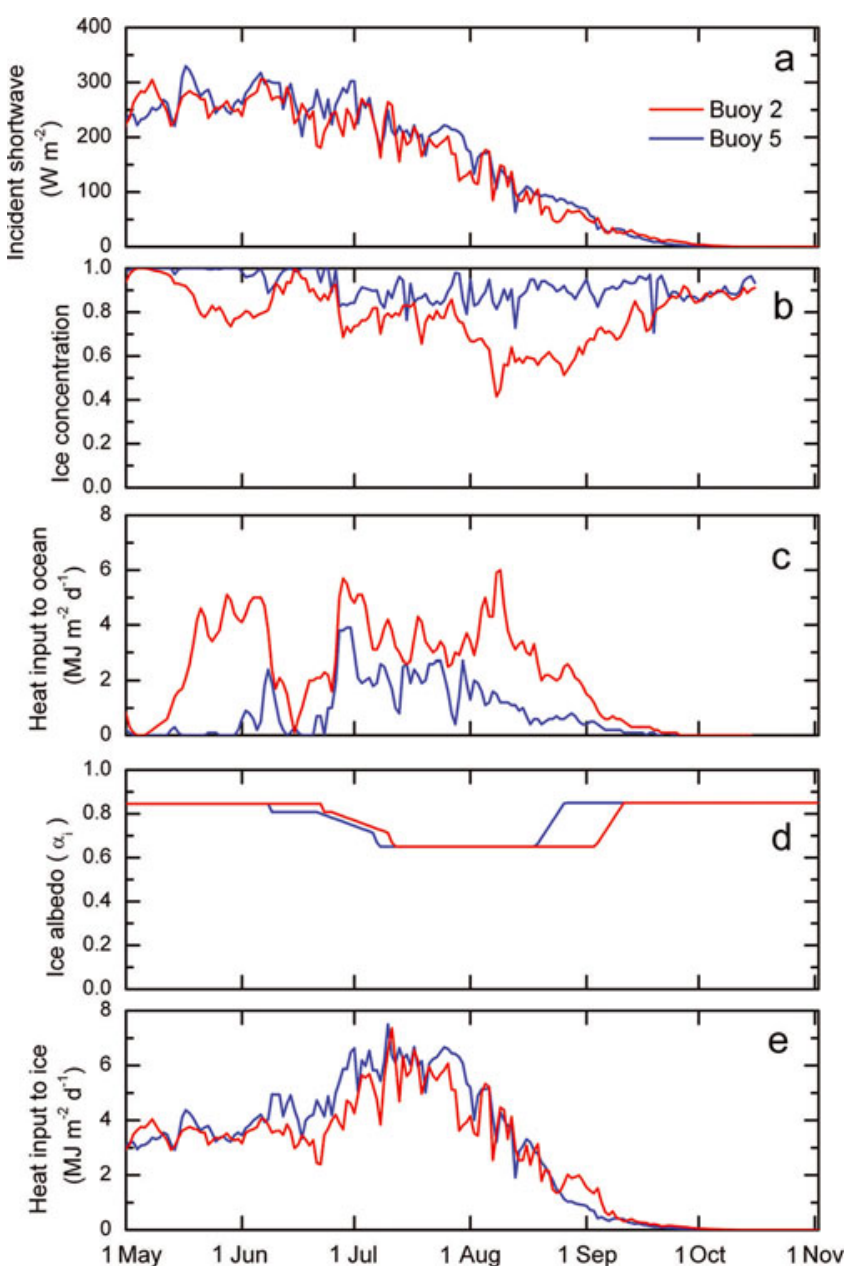

Fig. 2. Time series of solar heating of the ice and upper ocean for the IMBs with a large amount of melt (buoy 2, red curve) and a small amount of melt (buoy 5, blue curve). (a) Incident shortwave irradiance; (b) ice concentration; (c) heat input to ocean; (d) ice albedo; and (e) heat input to the ice. 

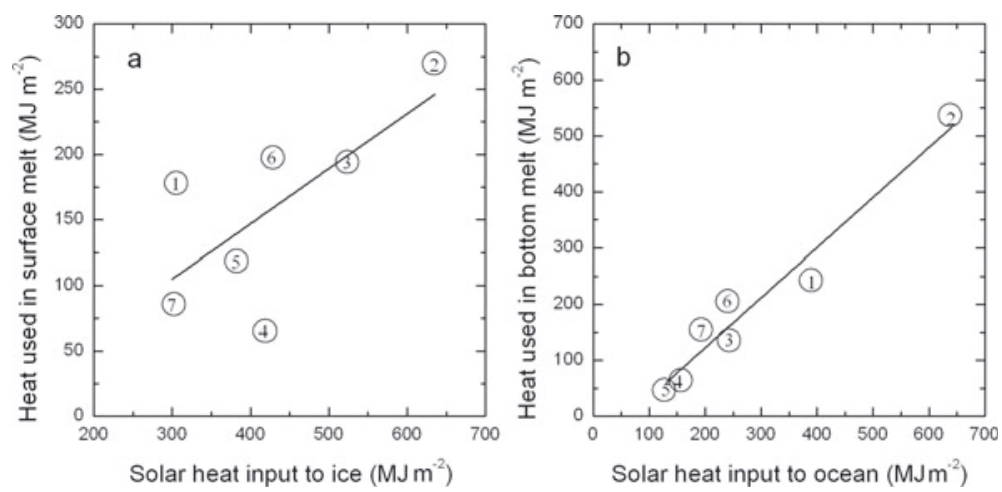

Fig. 3. Solar heat input and melting. Comparison of (a) heat used in surface melting, $Q_{\mathrm{ms}}$, to solar heat input to ice, $Q_{\mathrm{i}}$, during the period of surface melting and (b) heat used in bottom melting, $Q_{\mathrm{mb}}$, to solar heat deposited in open water, $Q_{\mathrm{w}}$. The straight lines are the linear leastsquares best fit to the data. In (a) the slope is 0.42 , with a correlation coefficient of 0.38 . In (b) the slope is 0.89 , with a correlation coefficient of 0.94 .

surface melting with increased solar heat deposited in the ice (Fig. 3a). The slope of the linear relationship is 0.42 , with a correlation coefficient of 0.38 and considerable scatter. For example, $\sim 600 \mathrm{~W} \mathrm{~m}^{-2}$ of solar heat absorbed in the ice resulted in surface melting ranging from 66 to $198 \mathrm{~W} \mathrm{~m}^{-2}$. This indicates that there are additional factors that influence surface ablation, which is not surprising as sensible heat, latent heat and longwave radiation also impact the surface heat budget. The net longwave radiation, in particular, has been established as a major factor in the surface heat budget and has a cooling effect on the surface in winter (Persson and others, 2002; Perovich and others, 2003). In summer the impact of net longwave radiation is more complex, with low clouds usually leading to enhanced surface melt.

The correlation is much stronger (correlation coefficient of 0.94 ) between the heat used in bottom melting and the solar heat deposited in the ocean (Fig. 3b). The slope of the line is 0.89 , indicating an almost one-to-one increase in bottom melting with solar heat input to the ocean. The relationship holds for observations that vary widely in geographic location, ice concentration and bottom melting. This argues that the primary source of heat for bottom melting of the ice is solar radiation absorbed in areas of open water (Maykut and McPhee, 1995; Perovich and others, 2008). For all seven of the buoys, there was more than enough solar energy deposited in the ice and in the ocean to provide the heat necessary for surface and bottom melting.

\section{CONCLUSIONS}

Surface-based observations of sea-ice mass balance at seven locations in the summer of 2008 showed considerable regional variability in surface and bottom melting. Total summer melt ranged from 0.37 to $3.17 \mathrm{~m}$. There was a strong linkage between solar heat input to the ocean and bottom melt. Variations in the solar heat input to the ocean were caused primarily by differences in ice concentration, with the largest amounts of bottom melting occurring in regions of reduced ice concentration.

These results have implications for a declining Arctic seaice cover. They indicate that decreases in ice concentration will lead directly to enhanced solar heat input to the ocean and increased bottom melting. Thinning of the ice will increase light transmission through the ice into the ocean, increasing melting in an ice-albedo feedback. In addition, earlier dates of melt onset will result in more solar heat input into the ice and more surface melting. Later dates of freezeup will have a similar result, but to a lesser extent.

\section{ACKNOWLEDGEMENTS}

We appreciate the support of the North Pole Environmental Observatory, the Beaufort Gyre Environmental Observatory and the DAMOCLES program for their efforts in deploying ice mass-balance buoys. This work has been funded by the US National Science Foundation, the National Aeronautics and Space Administration, and the National Oceanographic and Atmospheric Administration.

\section{REFERENCES}

Comiso, J.C., C.L. Parkinson, R. Gersten and L. Stock. 2008. Accelerated decline in the Arctic sea ice cover. Geophys. Res. Lett., 35(1), L01703. (10.1029/2007GL031972.)

Francis, J.A. and E. Hunter. 2006. New insight into the disappearing Arctic sea ice. Eos, 87(46), 509.

Gascard, J.-C. and 25 others. 2008. Exploring Arctic transpolar drift during dramatic sea ice retreat. EOS, 89(3), 21-28.

Giles, K.A., S.W. Laxon and A.L. Ridout. 2008. Circumpolar thinning of Arctic sea ice following the 2007 record ice extent minimum. Geophys. Res. Lett., 35(22), L22502. (10.1029/2008GL035710.)

Haas, C., A. Pfaffling, S. Hendricks, L. Rabenstein, J.-L. Etienne and I. Rigor. 2008. Reduced ice thickness in Arctic Transpolar Drift favors rapid ice retreat. Geophys. Res. Lett., 35(17), L17501. (10.1029/2008GL034457.)

Kay, J.E., A. Gettelman, G. Stephens and C. O'Dell. 2008. The contribution of cloud and radiation anomalies to the 2007 Arctic sea ice extent minimum. Geophys. Res. Lett., 35(8), L08503. (10.1029/2008GL033451.)

Kwok, R., G.F. Cunningham, M. Wensnahan, I. Rigor, H.J. Zwally and D. Yi. 2009. Thinning and volume loss of the Arctic Ocean sea ice cover: 2003-2008. J. Geophys. Res., 114(C7), C07005. (10.1029/2009JC005312.)

Liu, J.P., J.A. Curry, W.B. Rossow, J.R. Key and X.J. Wang. 2005. Comparison of surface radiative flux data sets over the Arctic Ocean. J. Geophys. Res., 110(C2), C02015. (10.1029/ 2004JC002381.)

Markus, T. and D.J. Cavalieri. 2000. An enhancement of the NASA Team sea ice algorithm. IEEE Trans. Geosci. Remote Sens., 38(3), 1387-1398.

Markus, T., J.C. Stroeve and J. Miller. 2009. Recent changes in Arctic sea ice melt onset, freezeup, and melt season length. J. Geophys. Res., 114(C12), C12024. (10.1029/2009JC005436.) 
Maslanik, J.A., C. Fowler, J. Stroeve, S. Drobot and H.J. Zwally. 2007. A younger, thinner Arctic ice cover: increased potential for rapid, extensive ice loss. Geophys. Res. Lett., 34(24), L24501. (10.1029/2007GL032043.)

Maykut, G.A. and M.G. McPhee. 1995. Solar heating of the Arctic mixed layer. J. Geophys. Res., 100(C12), 24,691-24,703.

Morison, J.H. and 10 others. 2002. North Pole environmental observatory delivers early results. EOS, 83(33), 357, 359, 361.

Nghiem, S.V., I.G. Rigor, D.K. Perovich, P. Clemente-Colón, J.W. Weatherly and G. Neumann. 2007. Rapid reduction of Arctic perennial sea ice. Geophys. Res. Lett., 34(19), L19504. (10.1029/2007GL031138.)

Pegau, W.S. and C.A. Paulson. 2001. The albedo of Arctic leads in summer. Ann. Glaciol., 33, 221-224.

Perovich, D.K. 2005. On the aggregate-scale partitioning of solar radiation in Arctic sea ice during the SHEBA field experiment. J. Geophys. Res., 110(C3), C03002. (10.1029/2004JC002512.)

Perovich, D.K., T.C. Grenfell, B. Light and P.V. Hobbs. 2002. Seasonal evolution of the albedo of multiyear Arctic sea ice. J. Geophys. Res., 107(C10), 8044. (10.1029/2000JC000438.)

Perovich, D.K., T.C. Grenfell, J.A. Richter-Menge, B. Light, W.B. Tucker, III and H. Eicken. 2003. Thin and thinner: ice mass balance measurements during SHEBA. J. Geophys. Res., 108(C3), 8050. (10.1029/2001JC001079.)

Perovich, D.K., B. Light, H. Eicken, K.F. Jones, K. Runciman and S.V. Nghiem. 2007. Increasing solar heating of the Arctic Ocean and adjacent seas, 1979-2005: attribution and role in the icealbedo feedback. Geophys. Res. Lett., 34(19), L19505. (10.1029/2007GL031480.)

Perovich, D.K., J.A. Richter-Menge, K.F. Jones and B. Light. 2008. Sunlight, water, and ice: extreme Arctic sea ice melt during the summer of 2007. Geophys. Res. Lett., 35(11), L11501. (10.1029/ 2008GL034007.)

Persson, P.O.G., C.W. Fairall, E.L. Andreas, P.S. Guest and D.K. Perovich. 2002. Measurements near the Atmospheric Surface Flux Group tower at SHEBA: near-surface conditions and surface energy budget. J. Geophys. Res., 107(C10), 8045. (10.1029/2000JC000705.)

Polyakov, I., D. Walsh, I. Dmitrenko, R.L. Colony and L.A. Timokhov. 2003. Arctic Ocean variability derived from historical observations. Geophys. Res. Lett., 30(6), 1298. (10.1029/2002GL016441.)

Richter-Menge, J. 2009. The Arctic. Bull. Am. Meteorol. Soc. 90, Special issue, S1-S196.

Richter-Menge, J.A., D.K. Perovich, B.C. Elder, K. Claffey, I. Rigor and M. Ortmeyer. 2006. Ice mass-balance buoys: a tool for measuring and attributing changes in the thickness of the Arctic sea-ice cover. Ann. Glaciol., 44, 205-210.

Rigor, I.G. and J.M. Wallace. 2004. Variations in the age of Arctic sea-ice and summer sea-ice extent. Geophys. Res. Lett., 31(9), L09401. (10.1029/2004GL019492.)

Rothrock, D.A., D.B. Percival and M. Wensnahan. 2008. The decline in arctic sea-ice thickness: separating the spatial, annual, and interannual variability in a quarter century of submarine data. J. Geophys. Res., 113(C5), C05003. (10.1029/2007JC004252.)

Serreze, M.C., J.R. Key, J.E. Box, J.A. Maslanik and K. Steffen. 1998. A new monthly climatology of global radiation for the Arctic and comparisons with NCEP-NCAR reanalysis and ISCCP-C2 fields. J. Climate, 11(2), 121-136.

Serreze, M.C., M.M. Holland and J. Stroeve. 2007. Perspectives on the Arctic's shrinking sea-ice cover. Science, 315(5818), 15331536.

Shimada, K. and 7 others. 2006. Pacific Ocean inflow: influence on catastrophic reduction of sea ice cover in the Arctic Ocean. Geophys. Res. Lett., 33(8), L08065. (10.1029/2005GL025624.)

Steele, M., W. Ermold and J. Zhang. 2008. Arctic Ocean surface warming trends over the past 100 years. Geophys. Res. Lett., 35(2), L02614. (10.1029/2007GL031651.)

Stroeve, J. and 7 others. 2008. Arctic sea ice extent plummets in 2007. EOS, 89(2), 13-14.

Walsh, J.E., W.L. Chapman and D.H. Portis. 2009. Arctic cloud fraction and radiative fluxes in atmospheric reanalyses. J. Climate, 22(9), 2316-2334.

Wang, M. and J.E. Overland. 2009. A sea-ice free summer Arctic within 30 years? Geophys. Res. Lett., 36(7), L07502. (110.1029/ 2009GL037820.)

Woodgate, R.A., K. Aagaard and T.J. Weingartner. 2006. Interannual changes in the Bering Strait fluxes of volume, heat and freshwater between 1991 and 2004. Geophys. Res. Lett., 33(15), L15609. (10.1029/2006GL026931.) 